\title{
PENGEMBANGAN ALAT PERMAINAN EDUKATIF ULAR TANGGA MATEMATIKA UNTUK MENINGKATKAN KEMAMPUAN BERHITUNG ANAK KELAS III SDN GUMININGREJO TIKUNG LAMONGAN
}

\author{
Nur Qomariyah Nawafilah ${ }^{1}$, Masruroh $^{2}$ \\ ${ }^{1,2}$ Teknik Informatika, Fakultas Teknik, Universitas Islam Lamongan \\ Jalan Veteran No. 53A Lamongan \\ $\underline{\text { nq.nawafil@yahoo.com }}{ }^{1}, \underline{\text { masruroh@unisla.ac.id }}{ }^{2}$
}

\begin{abstract}
ABSTRAK
Sekolah Dasar merupakan tingkat pendidikan formal yang masih tergolong awal. Pada tingkat ini terdapat beberapa aspek yang harus dikuasai siswa seperti aspek kogtinif, motorik, dan psikomotor. Salah satu kemampuan dalam aspek kognitif yang harus dikuasai siswa adalah kemampuan berhitung. Berhitung adalah salah satu tugas belajar anak yang harus bisa dipelajari dengan baik selain belajar menulis dan membaca. Agar kemampuan berhitung anak dapat berkembang dengan baik, maka sebaiknya guru dapat melaksanakan proses pembelajaran melalui kegiatan bermain sambil belajar atau belajar sambil bermain, karena bermain adalah cara anak dalam belajar. Ular Tangga Matematika adalah permainan edukatif yang dikembangkan dengan memodifikasi permainan ular tangga pada umumnya. Permainan ini dibuat dengan tujuan agar kemampuan berhitung siswa kelas III SDN Guminingrejo dapat meningkat melalui aktivitas bermain ini. Metode yang akan digunakan dalam penelitian ini adalah metode deskriptif, sedangkan pendekatan yang akan digunakan adalah pendekatan kualitatif. Setelah permainan ini diterapkan dalam pembelajaran dapat disimpulkan bahwa: 1) Produk Ular tangga matematika dapat meningkatkan kemampuan berhitung anak, 2) kualitas produk termasuk layak untuk diterapkan dalam pembelajaran, 3) produk dapat menghasikan tercapainya tujuan pembelajaran, 4) penerapan produk dapat meningkatkan movitasi belajar anak karena belajar terasa tidak membosankan.
\end{abstract}

Kata Kunci: Alat permainan edukatif, Ular tangga Matematika, kemampuan berhitung

\begin{abstract}
Elementary school is a level of formal education that is still relatively early. At this level there are several aspects that must be mastered by students such as cogtinif, motoric, and psychomotor aspects. One ability in the cognitive aspects that students must be mastered is the ability to calculate. Calculation is one of the children's learning tasks that must be well learned besides learning to write and read. In order to children's calculate skills develop properly, the teacher should be able to carry out the learning process through play activities while learning or learning while playing, because playing is the child's way of learning. Mathematics Snakes and Ladders is an educational game developed by modifying snakes and ladders games in general. This game was made with the aim that the calculate ability of Grade III students at Guminingrejo Elementary School could be increased through this play activity. The method that will be used in this research is descriptive method, while the approach to be used is a qualitative approach. After this game is applied in learning, it can be concluded that: 1) The product of the Mathematical ladder snake can improve children's calculate skills, 2) the quality of the product is feasible to be applied in learning, 3) the product can achieve the achievement of learning objectives, 4) the application of the product can increase learning motivation children because learning feels not boring.
\end{abstract}

Keywords: Educational game tool, Mathematics snakes and ladders, calculate skills 


\section{PENDAHULUAN}

Sistem pendidikan nasional adalah keseluruhan komponen pendidikan yang saling terkait secara terpadu untuk mencapai tujuan pendidikan nasional. Pendidikan nasional sendiri adalah pendidikan yang berdasarkan pancasila dan UUD negara republik Indonesia tahun 1945 yang berakar pada nilai-nilai agama, kebudayaan nasional Indonesia, dan tanggap terhadap tuntutan perubahan zaman. Berdasarkan UU Nomor 20 Tahun 2003 Pasal 1 ayat 6 dituliskan bahwa pendidik adalah tenaga kerja yang berkualifikasi sebagai guru, dosen, konselor, pamong belajar, dan sebutan lain yang sesuai dengan kekhususannya, serta berpartisipasi dalam menyelenggarakan pendidikan.

Pendidikan adalah proses belajar yang dilaksanakan oleh individu atau kelompok untuk memperoleh pengetahuan, wawasan, serta membantu individu mengembangkan keterampilan dan sikap dalam mempersiapkan kehidupan mendatang. Pendidikan dimulai sejak dini tanpa mengenal batas usia. Berawal pendidikan dari orang tua, keluarga, lingkungan sekitar sehingga dapat berkembang secara optimal dan sesuai harapan.

Sekolah Dasar merupakan tingkat pendidikan formal yang masih tergolong awal. Pada tingkat ini terdapat beberapa aspek yang harus dikuasai siswa seperti aspek kogtinif, motorik, dan psikomotor. Salah satu kemampuan dalam aspek kognitif yang harus dikuasai siswa adalah kemampuan berhitung. Menurut Ariyanti \& Muslimin (2015), Berhitung adalah salah satu tugas belajar anak yang harus bisa dipelajari dengan baik selain belajar menulis dan membaca.

Yusuf (2003) mengungkapkan jika kesulitan belajar berhitung merupakan jenis kesulitan belajar terbanyak selain membaca dan menulis. Nevid dan Beverly (2009) berpendapat bahwa anak-anak yang memiliki hambatan perkembangan yang buruk dalam kemampuan berhitung, membaca, dan menulis akan menghambat prestasi sekolahnya. Mereka cenderung berprestasi buruk di sekolah dan sering dinilai gagal oleh guru maupun keluarga mereka. Tidak heran jika mereka yang memiliki prestasi yang buruk akan mengembangkan ekspektasi yang rendah dan bermasalah dengan self esteem. Oleh karena itu, penanaman konsep berhitung, menulis, maupun membaca harus diajarkan sejak dini seperti yang dikemukakan oleh Glen Domen (dalam Prihastuti, 2009) bahwa persiapan belajar berhitung harus dimulai sejak anak masih berusia dini.

Agar kemampuan berhitung anak dapat berkembang dengan baik, maka sebaiknya guru dapat memahami tahap kemampuan berhitung anak dan melaksanakan proses pembelajaran 
melalui kegiatan bermain sambil belajar atau belajar sambil bermain, karena bermain adalah cara anak dalam belajar. Menurut Hartati (2005:85), bermain adalah sebuah sarana yang dapat mengembangkan anak secara optimal. Suyadi (2009) mengungkapkan jika bermain adalah suatu perbuatan yang dilakukan oleh seorang anak untuk menyenangkan hati dengan menggunakan alat-alat tertentu maupun tidak. Dengan pola belajar sambil bermain dan pola bermain sebagaimana belajar, maka anak merasa nyaman. Alasannya, tanpa sengaja anak bermain sambil belajar dalam permainan dan bermain dalam belajar. Antara belajar dan bermain sama-sama menyenangkan sekaligus menantang. Kondisi belajar yang menyenangkan sekaligus menantang inilah yang mempunyai potensi besar membentuk karakter anak menjadi seorang pembelajar sejati. Hasil belajar anak meningkat tajam karena semakin banyak permainan yang dilakukannya semakin menambah tingkat kecerdasannya. Lebih dari itu, kelak di masa dewasa, bahkan hingga di masa tua, ia akan mempunyai hobi yang sangat mengagumkan, yakni belajar. Ia menikmati belajar sama dengan menikmati permainan. Perasaan ini yang mendorong anak untuk belajar setiap saat, tanpa disuruh dan diawasi (Suyadi,2009).

Mansur (2007) berpendapat bahwa perkembangan bermain sebagai cara pembelajaran hendaknya disesuaikan dengan perkembangan umur dan anak didik. Perkembangan kognitif anak usia kelas rendah (kelas I-III ) menurut Piaget (Nurhayati, 2011) anak sudah mampu untuk mengklasifikasikan angka-angka atau bilangan meskipun masih harus banyak menggunakan benda atau objek yang konkret seperti alat peraga. Selama ini metode yang digunakan oleh guru kelas III di SDN Guminingrejo hanya sebatas metode ceramah, pemberian tugas dan tanpa menggunakan alat peraga. Salah satu alat peraga yang bisa digunakan selama proses pembelajaran adalah dengan menggunakan alat permainan edukatif seperti Ular Tangga Matematika. Adiarti (2009) berpendapat bahwa bermain akan lebih baik bila kegiatan yang dilakukan anak memiliki muatan edukatif, sehingga aktivitas yang dilakukan dapat mengembangkan semua aspek perkembangan anak.

Ular Tangga Matematika adalah permainan edukatif yang dikembangkan dengan memodifikasi permainan ular tangga pada umumnya. Permainan edukatif ini dibuat dengan tujuan agar kemampuan berhitung siswa kelas III SDN Guminingrejo dapat meningkat melalui aktivitas bermain ini. Penelitian mengenai pengembangan media Ular Tangga Matematika ini penting untuk dikaji dengan maksud agar guru mendapatkan pengetahuan baru dalam proses pembelajaran. 


\section{METODE}

Metode yang akan digunakan dalam penelitian ini adalah metode deskriptif, sedangkan pendekatan yang akan digunakan adalah pendekatan kualitatif. Menurut Putra dan Dwilestari (2012: 70), deskriptif adalah semua kegiatan baik yang dikatakan maupun dilakukan oleh para pelaku beserta proses yang sedang berlangsung dan berbagai aktivitas lain dalam konteks seluruhnya adalah alamiah.

Teknik pengumpulan data yang digunakan dalam penelitian ini adalah observasi, wawancara dan studi dokumenter. Adapun penjelasan masing-masing teknik pengumpulan data disajikan sebagai berikut.

Teknik observasi yakni penelitian dilakukan dengan cara mengadakan pengamatan terhadap suatu objek, baik secara langsung maupun tidak langsung. Menurut Sugiyono (2012: 310), dalam observasi peneliti terlibat langsung dengan kegiatan sehari-hari orang yang sedang diamati atau yang digunakan sebagai sumber data penelitian. Observasi merupakan suatu kegiatan yang memusatkan perhatian terhadap suatu objek dengan menggunakan alat penglihatan, pedengaran, penciuman, dan bila perlu melalui pengecapan dan perabaan.

Agar kegiatan observasi dapat terarah dan informasi yang dibutuhkan didapat sesuai dengan harapan penelitian, maka dibuat batasan tentang apa yang akan diamati. Dalam pelaksanaan kegiatan observasi ini ditujukan untuk guru dan anak yang diarahkan pada kegiatan (1) perencanaan pembelajaran, (2) pelaksanaan pembelajaran, (3) hasil pembelajaran serta (4) aktivitas anak dalam bermain.

Teknik wawancara digunakan dalam proses pengumpulan data apabila peneliti ingin memperdalam informasi yang diterima. Wawancara dilakukan untuk melengkapi data yang dibutuhkan dan untuk mendapatkan kejelasan dan hasil observasi yang dilakukan. Subjek penelitian diminta untuk memberikan informasi sesuai dengan apa yang pikirkan dan dirasakannya.

Menurut Sugiyono (2008: 72) wawancara dilakukan untuk mengetahui hal-hal yang lebih mendalam tentang partisipan dalam menginterprestasikan situasi dan fenomena yang terjadi.

Dalam penelitian ini dibutuhkan keterangan tentang kegiatan guru dalam memanfaatkan alat permainan edukatif melalui pembelajaran matematika menggunakan media ular tangga matematika. Selain itu perlu digali juga informasi dari siswa sebagai pemain dalam media edukatif ular tangga matematika. 
Melalui wawancara peneliti mengetahui apa yang terkandung dalam pikiran dan hati responden. Hal-hal yang tidak dapat diketahui melalui observasi dapat peneliti gunakan sebagai pedoman wawancara agar kegiatan wawancara terarah pada fokus penelitian. Pedoman tersebut sifatnya tidak terlalu ketat sehingga dapat dikembangkan dan diubah sesuai dengan kebutuhan penelitian. Dalam penelitian ini wawancara kepada guru untuk mendapatkan informasi tentang mekanisme perencanaan, pelaksanaan pembelajaran dengan pemanfaat alat permainan edukatif ular tangga matematika.

Teknik pengumpulan data studi dokumenter juga digunakan untuk melengkapi teknik observasi dan wawancara. Sebagaimana dikemukakan oleh Sugiyono (2008: 82) bahwa dokumen merupakan catatan peristiwa yang sudah berlaku. Dokumen bisa berbentuk tulisan, gambar, atau karya-karya monumental dari seseorang.

Studi dokumentasi berguna karena dapat memberikan gambaran yang lebih jelas mengenai pokok penelitian berupa pemanfaatan alat permainan edukatif, model pembelajaran yang dilakukan, dan keterampilan motorik anak. Data yang ingin didapatkan melalui studi dokumentasi adalah informasi mengenai pemanfaatan alat permainan edukatif meliputi perencanaan, pelaksanaan dan hasil perkembangan anak.

Peneliti sebagai instrumen utama dalam mengumpulkan data menggunakan alat pengumpul data berupa lembar observasi, pedoman wawancara dan dokumentasi. Dalam studi dokumentasi peneliti ingin mendapatkan informasi tentang kegiatan pembelajaran yang dilakukan guru dalam pengembangan alat permainan edukatif ular tangga matematika.

Teknik menganalisa data dalam penelitian merupakan suatu pekerjaan penting untuk dilakukan, karena melalui kegiatan tersebut peneliti akan mendapatkan makna terhadap data yang diperoleh. Seperti yang dikemukakan oleh Sugiyono (2008: 87) menyatakan bahwa "teknik analisis data yang digunakan untuk menjawab rumusan masalah atau menguji hipotesis yang dirumuskan dalam penelitian”.

Prosedur analisis data dalam penelitian ini yaitu: (1) reduksi, (2) display data, dan (3) mengambil kesimpulan. Menutur Huberman (dalam Sugiyono 2008: 91) analisis data dilakukan pada saat pengumpulan data berlangsung. Prosedur analisis yang meliputi reduksi data, penyajian data, penarikan kesimpulan. Prosesnya dibuat perencanaan lalu dikumpulkan data dan setelah data terkumpul selanjutnya di analisis, kemudian disajikan dan ditarik kesimpulan. Sedangkan Chariri (2008: 17) Untuk melakukan analisis, peneliti perlu menangkap, mencatat, menginterpretasikan dan menyajikan informasi. Satu hal yang perlu 
diperhatikan oleh peneliti adalah dalam penelitian kualitatif, analisis data tidak dapat dipisahkan dari data collection.

Analisis dalam penelitian kualitatif berlangsung bersamaan dengan proses pengumpulan data dan sampai melalui tiga tahap lainnya yang dilakukan secara simultan dan berkesinambungan. Untuk lebih jelasnya tahapan-tahapan analisis itu akan diuraikan sebagai berikut:

\section{Reduksi Data}

Reduksi data merupakan proses pemilihan atau pemusatan perhatian, penyederhanaan, pengabstrakan, dan transformasi data kasar dari data yang muncul dalam catatan-catatan yang tertulis dan merupakan hasil survei pada saat peneliti berada di lapangan.

2. Penyajian Data

Penyajian data diartikan sebagai perangkat informasi yang teroganisir, yang memungkinkan dilakukan penarikan kesimpulan. Penyajian data lebih terfokus mungkin mencakup ringkasan-ringkasan terstruktur, sinopsis, kerangka dan diagram. Hal ini mempermudah peneliti untuk secara keseluruhan atau bagian-bagian tertentu dari penelitian ini.

\section{Penarikan Kesimpulan}

Penarikan kesimpulan yaitu arti dari data yang dikumpulkan yang melibatkan pemahaman peneliti. Penarikan kesimpulan ini peneliti lakukan sejak awal data dikumpulkan. Walaupun kesimpulan pada awalnya masih bersifat kabur namun dengan bertambahnya data maka kesimpulan menjadi jelas.

\section{HASIL DAN PEMBAHASAN}

Penelitian ini dilaksanakan di SDN Guminingrejo Tikung Lamongan pada bulan Juli 2019 dan berakhir pada bulan Agustus 2019. Untuk memberikan gambaran secara rinci mengenai kondisi SDN Guminingrejo, maka peneliti memaparkan kondisi nyata berikut.

SDN Guminingrejo Tikung Lamongan dengan NISN: 100190, NPSN: 20506211, dan NSS: 101050714025 beralamat di Dusun Gumining Desa Guminingrejo Kec. Tikung Kab. Lamongan Provinsi Jawa Timur. Saat ini status sekolah adalah Negeri dalam naungan Dinas Pendidikan Kabupaten Lamongan. 


\section{Pembuatan produk}

Pembuatan produk ini diawali dengan mendesain produk menggunakan aplikasi photoshop cs6. Papan ular tangga didesain berbentuk persegi panjang dengan ukuran $2 \times 2,5$ $\mathrm{m}$ dan terdapat 25 petak yang didesain dengan warna dan gambar yang menarik. Peneliti juga membuat 25 kartu soal yang mana semakin tinggi nomor petak maka semakin sulit pula soal di dalamnya. Pembuatan desain media berlangsung selama 1 bulan. Setelah selesai kemudian dicetak, untuk papan ular tangga menggunakan bahan banner ukuran 2 x 2,5 m. Sedangkan kartu soal menggunakan kertas buffalo yang dipotong kecil. Untuk peraturan permainan sudah tertulis di bagian bawah papan ular tangga. Peraturannya adalah sebagai berikut:

1. Pemain mulai dengan melempar dadu dan menempati kotak sesuai angka yang sesuai

2. Pemain menjawab soal dari kartu soal sesuai nomor kotak yang ditempati.

3. Jika berhasil menjawab dengan benar pemain dapat menempati kotak tersebut, namun jika salah pemain mundur satu langkah.

4. Jika kotak yang ditempati adalah kotak tangga maka pemain dapat menaiki tangga tersebut apabila berhasil menjawab soal dengan benar, namun jika salah maka pemain tetap dikotak tersebut tanpa menaiki tangga.

5. Jika kotak yangditempati adalah kotak ular maka pemain yang dapat menjawab dengan benar tetap di kotak tersebut, namun jika salah maka pemain harus menuruni ular.

6. Pemain dinyatakan menang apabila telah mencapai kotak finish.

Selain kartu soal diperlukan pula dadu berukuran 15 x $15 \mathrm{~cm}$ yang terbuat dari kain flannel. Berikut adalah gambaran desain ular tangga matematika, dadu, dan kartu soal.
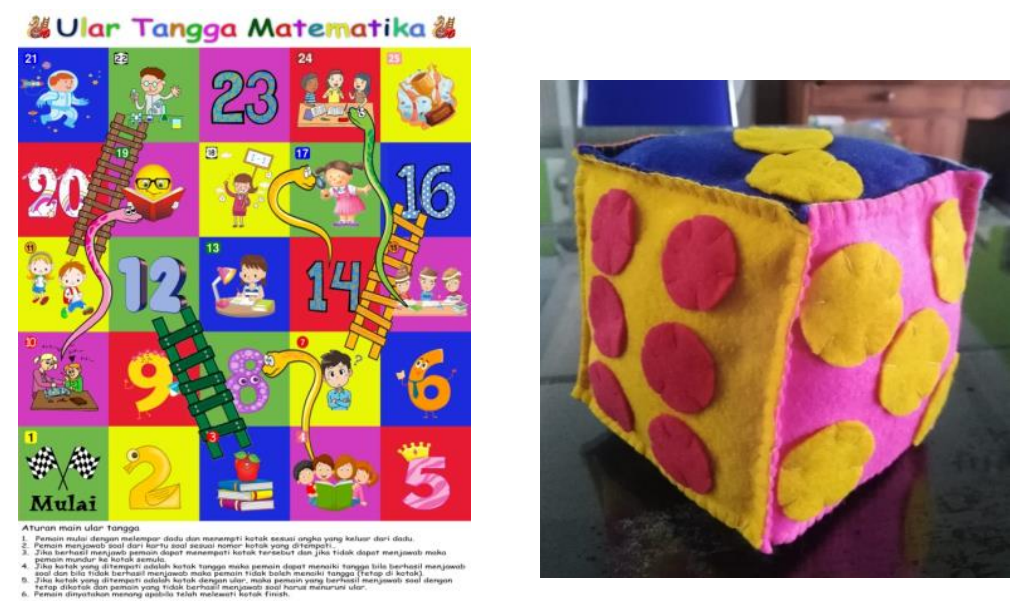

Gambar 1. Desain Ular tangga Matematika dan Dadu 

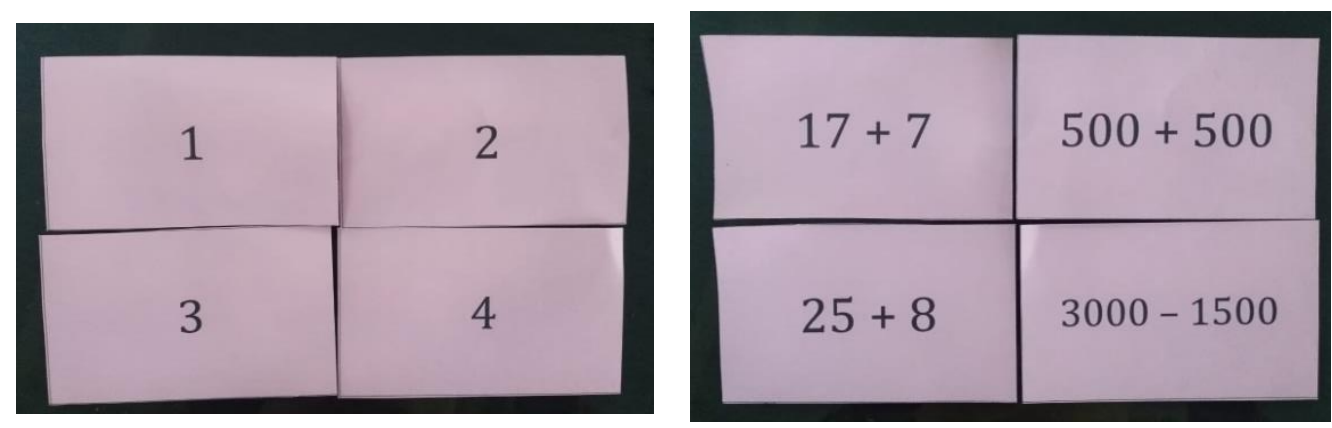

Gambar 2. Kartu Soal (kiri: nomor kartu, kanan: soal)

\section{Hasil Uji Siswa}

Berdasarkan angket yang telah diisi oleh siswa kelas III SDN Guminingrejo sebanyak 13 anak pada pelaksanaan, didapatkan data penilaian terhadap alat permainan edukatif berjumlah 121 jawaban "Setuju" dari jumlah total maksimal penilaian 130. Jumlah skor tersebut dipersentasikan menjadi 93\% dan dapat disimpulkan bahwa alat permainan edukatif ular tangga matematika sangat layak untuk digunakan.

\section{Hasil Uji Guru}

Data numerik hasil uji guru menunjukkan bahwa rerata skor akhir yang diperoleh adalah 3,32. Secara lengkap rerata skor hasil uji guru kelas III terhadap alat permainan edukatif dalam meningkatkan kemampuan berhitung pada anak kelas III SDN Guminingrejo seperti tampak pada tabel berikut.

Tabe1 1. Hasil Penilaian Guru Kelas III SDN Guminingrejo

\begin{tabular}{|c|c|c|c|}
\hline Aspek & Rata-rata & Persentase & Kategori \\
\hline Pembelajaran & 3,32 & $84 \%$ & Baik \\
\hline
\end{tabular}

Komentar yang diberikan Guru kelas III SDN Guminingrejo terhadap permainan ular tangga matematika bahwa media ini merupakan alat permainan edukatif yang menyenangkan, dapat memotivasi anak-anak dalam belajar menghitung karena ada target yang ingin dicapai yakni ingin sampai di nomor petak terakhir paling awal. Bagi kelompok yang mencapai titik finish paling awal akan mendapatkan reward. Namun sebaiknya, soal yang terdapat pada kartu soal diturunkan sedikit tingkat kesulitannya karena masih banyak siswa yang merasa kesulitan dan membutuhkan waktu lama untuk dapat menjawabnya. 


\section{Pembahasan}

Berdasarkan hasil dari penelitian selama kegiatan pembelajaran berlangsung anak sudah mulai antusias untuk mengikuti pembelajaran, berdasarkan temuan-temuan peneliti mencoba mencari pemecahan atas masalah yang timbul dalam rangka meningkatkan kemampuan berhitung pada anak, dengan upaya menggunakan media yang menunjang salah satunya dengan menggunakan media ular tangga matematika.

Ular tangga matematika sebagai salah satu media dalam kegiatan proses belajar mengajar dalam belajar berhitung sangat bermanfaat bagi siswa. Diantaranya adalah:

1. Melatih siswa untuk dapat mencapai target dengan berhitung secara benar dan menyenangkan.

2. Mencegah siswa belajar hanya pada tingkah verbal saja.

3. Berekspresi sesuai dengan caranya sendiri yang masih dapat diterima oleh sekelilingnya.

Berdasarkan hasil wawancara yang dilakukan dengan guru, sebelumnya guru belum pernah melakukan pengajaran dengan menggunakan media pembelajaran alat permainan edukatif. Selama ini, guru hanya menggunakan metode pembelajaran langsung atau ceramah dan buku teks berhitung yang membuat siswa jenuh dan kurang antusias dalam kegiatan pembelajaran. Oleh karena itu, guru sangat antusias dengan adanya media ular tangga matematika ini karena dapat meningkatkan kemampuan berhitung siswa. Berikut ini adalah dokumentasi penerapan ular tangga matematika dalam pembelajaan di kelas.
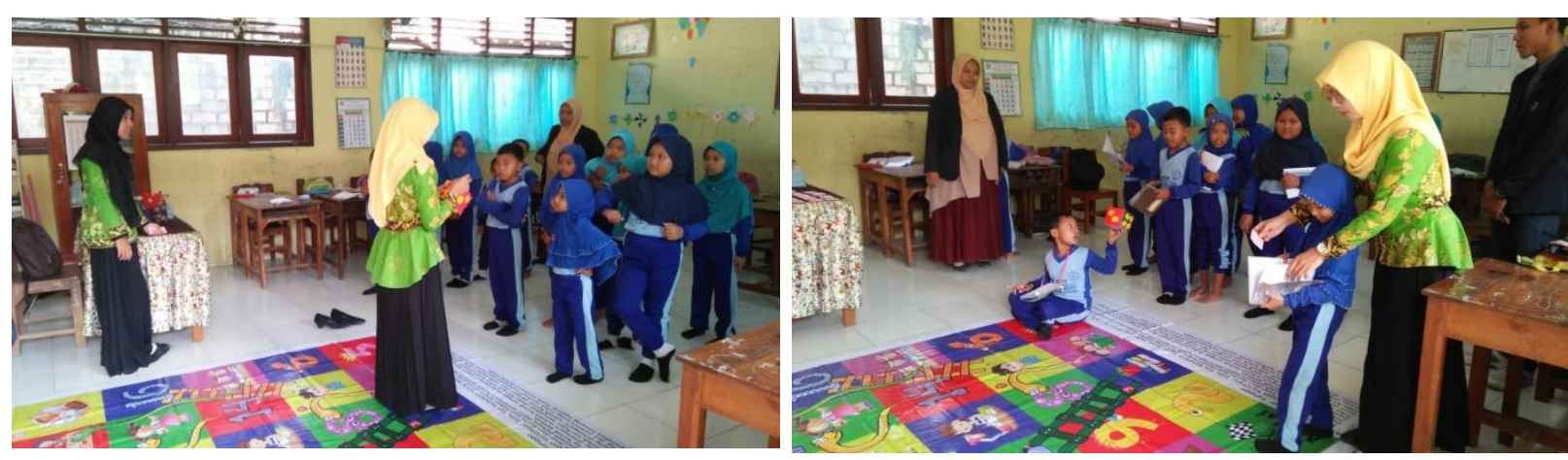

Gambar 2. Penerapan Ular Tangga Matematika dalam Pembelajaran di Kelas

\section{SIMPULAN}

Berdasarkan hasil dan pembahasan yang telah dipaparkan pada bab sebelumnya, maka dapat disimpulkan sebagai berikut: 1) Produk Ular tangga matematika dapat digunakan 
untuk meningkatkan kemampuan berhitung anak, 2) kualitas produk ular tangga matematika termasuk dalam kategori layak untuk diterapkan sebagai media pembelajaran, 3) efektifitas ular tangga matematika dalam pembelajaran dapat menghasikan tercapainya tujuan pembelajaran, 4) penerapan produk ular tangga matematika dapat meningkatkan movitasi belajar anak karena belajar terasa tidak membosankan.

\section{DAFTAR PUSTAKA}

Adiarti, W. 2009. Alat Permainan Edukatif Berbahan Limbah dalam Pembelajaran Sains Di Taman Kanak-Kanak. Jurnal Ilmu Kependidikan, 1, 78-84.

Hartati, Sofia. 2005. Perkembangan Belajar pada Anak Usia Dini. Jakarta: Departemen Pendidikan Nasional Direktorat Jendral Pendidikan Tinggi Direktorat Pembinaan Pendidikan Tenaga Kependidikan dan Ketenagaan Perguruan Tinggi.

Mansur. 2007. Pendidikan Anak Usia Dini dalam Islam. Yogyakarta: Pustaka Pelajar.

Nevid, S dan Beverly, G. 2009. Psikologi Abnormal. Jilid II Edisi kelima. Jakarta : Erlangga.

Nurhayati, E. 2011. Psikologi Pendidikan Inovatif. Yogyakarta: Pustaka Pelajar.

Prihastuti. 2009. Pengaruh Braingym dalam Meningkatkan Kecakapan Berhitung Pada Siswa Sekolah Dasar. Jurnal Cakrawala Pendidikan 1, 35-47.

Putra, Nusa \& Dwilestari, Ninin. 2012. Penelitian Kualitatif PAUD. Jakarta: PT Raja Grafindo Persada.

Sugiyono. 2008. Memahami Penelitian Kualitatif. Bandung: Alfabet

Sugiyono. 2012. Metode Penelitian Kuantitatif dan R\&D. Bandung: Alfabeta.

Suyadi. 2009. Permainan Edukatif yang Mencerdaskan. Yogyakarta: Power Books (IHDINA).

Undang-undang RI No. 20 tahun 2003 tentang Sistem Pendidikan Nasional. 2003. Jakarta: PT Armas Duta Jaya.

Yusuf, M. 2003. Pendidikan Bagi Anak dengan Problem Belajar. Solo: PT Tiga Serangkai Pustaka Mandiri. 